\title{
LES ARRELS MONOTEISTES DE LA FONAMENTALITZACIO
}

\author{
Lluís Duch \\ MONESTIR DE MONTSERRAT
}

\section{Introducci 6}

Es un fet a bastament conegut que les èpoques històriques marcades per crisis globals són molt propícies a extensives i intensives fonamentalitzacions dels diversos aspectes que configuren l'existència humana. La manca d'orientací $\mathrm{col} \cdot$ lectiva $^{1}$, la pèrdua dels criteris fins aleshores valids per fer front a les emergències de l'existència humana, el desencís provocat per la manca de correspondència entre les expectatives que hom albirava i els resultats pràctics que $s$ 'han assolit, es troben a la base, entre molts d'altres factors, de la irrupció d'actituds i de comportaments realment fonamentalistes o, almenys potencialment, susceptibles d'esdevenir-ho. En aquest moment, els sistemes socials en llur conjunt comencen a experimentar una aguda pèrdua de legitimació, la qual cosa empeny molts a cercar "legitimacions suplementàries i infal-libles" que els estalviin el risc d'equivocar-se i de plantejar-se amb esperit crític la recerca d'uns nous criteris més actualitzats $^{2}$. No hi ha dubte que, aleshores, la negativitat del moment present que hom viu i la sospita del seu increment en el futur que s'apropa, imposen molt sovint una "fugida vers la radicalitat"3, a fi de consolidar en la vida quotidiana "un" (que acostuma a ser el) "règim de la veritat" sense possibilitat d'error, dubte, ambigūitat o discussió

Hom tampoc no hauria d'oblidar que els moments marcats fortament per la irrellevància dels criteris tradicionals acostumen a provocar una profunda desestructuració psico-emocional de l'individu, la qual, freqūentment, es caracteritza per un vertiginós augment del dubte i de la

${ }^{1}$ Sobre el concepte "orientacio" en el sentit que acf l'emprem, vegeu H. Lübbe, " Orientierung". Zur Karriere eines Themas": Der Mensch als Orientierungswaise? Ein interdisziplinărer Erkundungsgang, Freiburg-München, Karl Alber, 1982, 7-29.

${ }^{2}$ J.A. Coleman, "El fundamentalismo en su globalidad. Perspectivas sociol6gicas": Concilium 241(1992), 67-81, ofereix, des d'una perspectiva sociològica, una de les analisis més lúcides sobre el fonamentalisme que coneixem. Des d'una perspectiva fenomenoldggica d'aquesta problemàtica, vegeu L. Duch, Temps de tardor. Entre modernitat i postmodenitat, Montserrat, Publicacions de I'Abadia de Montserrat, 1990, 222-251, 280-310; Id., "L'allau fonamentalista. Consideracions critiques" a Qllestions de Vida Cristiana 159(1991), 7-27; Id., Les dimensions religioses de la comunitat, Montserrat, Publicacions de I'Abadia de Montserrat, 1992, 130-153; Id., "Tradición y fundamentalismo" (en premsa).

${ }^{3}$ Vegeu St.H. Pfürtner, Fundamentalismus. Die Fucbt ins Radikale, Freiburg-Basel-Wien, Herder, 1991.

${ }^{4}$ Cfr. E. Pace, $l$ regime della verita. Il fondamentalismo religioso contemporaneo, Bologna, II Mulino, 1990. 
perplexitat $\mathrm{i}$, en alguns individus més vulnerables, per una perillosa immersió en l'angoixas. Per aixd no resulta estrany que, aleshores, el fanatisme, el dogmatisme i el fonamentalisme s'imposin en nombrosos individus, que, personalment, es consideren greument amenaçats per una situació social que ha esdevingut totalment desconeguda i indominable, i que, en consequiència, ofereix trets summament inquietants ${ }^{6}$. La llibertat -l'exercici de la llibertat- comporta un enorme risc: el fonamentalisme acostuma a ser, com ho ha posat en relleu Jörg Splett, una fugida vers l'esclavatge, per tal d'evitar el risc, l'angoixa i la perillositat de l'exercici de la llibertat'. Com deia Carl Gustav Jung, molt sovint, el fanatisme és el germà del dubte.

En apropar-se a les variadíssimes formes de la fonamentalització, hom no hauria de perdre de vista que el concepte "fonamentalisme" resulta summament imprecís, ja que amb la mateixa etiqueta hom designa fenòmens molt diversos que, sovint, són pràcticament irreconciliables entre $\mathrm{si}^{\mathrm{i}}$. Si hom, per exemple, en el camp religios i d'acord amb l'esquema proposat per Max Weber, distingeix entre unes actituds que afirmen el món (Weltbejahung) $i$ unes altres que neguen el món (Weltablehnung) o, per dir-ho més senzillament, entre dominació del món o adaptació al món i fugida del món, s'obtenen dos models de fonamentalisme i de processos de fonamentalització completament diferents. En el primer cas, hom cerca la constitució d'un ordre i d'una seguretat socials mitjançant l'establiment d'unes estructures socials adequadament regulades, mentre que en el segon cas, hom s'interessa primordialment per la configuració d'una comunitat ideal (nomundana), que cal que no es preocupi pels afers i pels interessos de la vida quotidiana. Amb tots els matisos que calgui tenir en compte, potser no resulti agosarat afirmar que els diversos fonamentalismes actuals es mouen entre aquests dos tipus ideals que tan sumàriament hem descrit.

En aquest article, però, no pretenem de portar a cap l'anàlisi socioldgica o psicològica dels actuals corrents fonamentalistes, sinó que, més aviat, ens proposem de seguir un camf indirecte que, al nostre entendre, ens permetrà de copsar les arrels ideològiques més profundes de la fonamentalització, sense perdre la connexió amb un dels trets més significatius de la cultura occidental: la concepció monoteista de la realitat.

Convé no oblidar, tanmateix, que els processos de fonamentalització no poden restringir-se, com d'habitud s'acostuma a fer, a l'àmbit de la religi $\sigma^{9}$. Es el conjunt de les diverses facetes de

Sobre el vessant psicologic del fonamentalisme, vegeu D. Funke, "Das balbierte Selbst. Psychische Aspeke des Fundamentalismus": H. Kochanek (ed.), Die verdrangte Freiheit. Fundamentalismus in den Kirchen, Freiburg-Basel-Wien, Herder, 1991, 83-93; Pfuirtner, Fundamentalismus, ja citat; G. Müller-Fahrenholz, " ${ }^{2}$ Qué es el fundamentalismo contemporáneo? Perspectivas psicológicas": Concilium 241(1992), 37-47; G. Hole, "Fundamentalismo, dogmatismo, fanatismo. Perspectivas psiquiátricas": id., 49-65.

'Sobre la distinció entre fanatisme, dogmatisme i fonamentalisme, vegeu l'article de Hole ja citat en la nota precedent. En aquest context, caldria referir-se al racisme com a forma molt important de fonamentalitzacio de l'existència husana, el qual s'aguditza en aquells moments, en els quals un sector de la població se sent amenaçada per una "emergència" exerior que posa en qũestió la real o suposada identitat personal i collectiva, la qual, sovint, tan sols s'expressa en termes oconònics.

${ }^{7}$ Vegeu J. Splett, "Flucht vor dem Freiheitsrisiko. Fundamentalismus aus der Sicht philosophischer Anthropologie": Kochanek (ed), Die verdrangte Freiheit, Op. cit., 72-82.

- Vegeu I'àmplia perspectiva interpretativa que traça K. Hoheisel, "Religiöser Fundamentalismus: Herkunft und Begriff: Kochanek, Die vendrangte Freiheit, Op. cit., 12-29, sobre l'origen i el sentit dels diversos usos del mot "fonamentalisme".

9 Vegeu, per exemple, l'interessant estudi de R.M. Nogues, "Biologia evolutiva i fonamentalisme", a Questions de Vida Cristiana 159(1991), 41-57, que analitza eis trets més importants dels processos de fonamentalització en la bioiogia contemporània. Una visió global de la fonamentalització de la cièneia moderna l'ofereix $\mathrm{H}$. Hemminger, "Fundamentalismus in Wissenschaft am Beispiel Kreationismus": H. Hemminger (ed.), Fundamentalismus in der verweltlichten Kultur, Stutgart, Quell, 1991, 163-195. Els moviments socials també poden sofrir l'impacte de la fonamentalització. Sobre la dels sindixats, 
l'existència humana que és susceptible de fonamentalitzar-se, ja que la fonamentalització és una possibilitat inherent (gairebé gosariem designar-la amb el terme "estructural") de l'ésser humà ${ }^{10}$.

\section{Un punt de partida: el monoteisme}

\subsection{Consideracions prèvies}

D'entrada, seguint Max Weber" i Emest Gellner ${ }^{12}$, voldríem establir una tallant diferència entre ortodðxia $\mathrm{i}$ heterod’̀xia (Weber) $^{13}$ o entre ciència i saviesa (Gellner) ${ }^{14}$; diferència que, al seu torn, dóna lloc a dues menes de fonamentalisme: un centrat en les doctrines $i$ les prescripcions de les escriptures sagrades, en el llibre (racional) i un altre centrat en l'experiència (carismàtic) ${ }^{15}$. El fonamentalisme "racional" exigeix dels seus adeptes que acomodin llur existència quotidiana d'acord amb l'única "logica" que es dedueix dels principis religiosos i morals continguts en les Escriptures Sagrades. En el fons, es tracta d'un estricte moralisme unidimensional, establert d'una vegada per totes, sense excepcions possibles, ahistòric, descontextualitzat, purità. El seu representant més qualificat acostuma a ser l'escriba o el predicador moral, que, per regla general, es comporten d'acord amb la coneguda figura dissenyada pel Führerprinzip, la qual és infarlible i "separada" ("sagrada") de la massa formada per les persones corrents. El fonamentalisme "carismàtic", en canvi, reconeix l'exigència ètica emanada de les Escriptures Sagrades, però hi afegeix, per tal que la salvació s'acompleixi de debò, la capacitat per assolir "gràcies" extraordinàries i no-quotidianes. Per aixठ, molt sovint, aquesta mena de fonamentalisme se centra en l'experiència religiosa, el miracle, l'extraquotidià. El representant típic no és el líder infallible amb matisos ètico-polítics, sinó el sant, el taumaturg, l'heroi, el màrtir.

Martin Riesebrodt ha posat en relleu que el fonamentalisme "racional" acostuma a ser adoptat pels habitants de les concentracions urbanes de classe mitjana, mentre que el fonamentalisme "carismàtic", més aviat, satisfa les necessitats i les expectatives extàtiques i

vegeu S. Miller, "Fundamentalistische Tendenzen in der frühen Arbeiterbewegung": Th. Meyer (ed.), Fundamentalismus in der modernen Welt. Die Internationale der Unvernunft, Frankfurt a.M., Suhrkamp, 1989, 195-212. Sobre la fonamentalització del marxisme, ef. H. Heimann, "Marxismus als Fundamentalismus?": Meyer (ed.), Op. cit., 213-230.

${ }^{10}$ Sobre la fonamentalització com a possibilitat inherent a l'ésser bumà, vegeu L. Duch, "Fundamentalismo y monoteísmo" (en premsa).

${ }^{11}$ Vegeu M. Weber, Gesammelte Aufsarze zur Religionssosiologie I, Tübingen, J.C.B. Mohr, "1972, 466-476.

${ }^{12}$ Cfr. E. Gellner, Muslim Society, Cambridge, Cambridge University Press, 1981, 114-130.

13 Sobre el problema de l'ortodoxia i de I'beterodoxia en Max Weber, efr. W. Schluchter, Religions und Lebensfuhrung. II: Studien zu Max Webers Religions- und Herrschaftssoziologie, Frankfurt a.M., Subrikamp, 1991, $120-126$.

${ }^{14}$ Sobre els "models argumentatius" de la saviesa, vegeu l'excellent volum collectiu editat per A. Assmann, Weisheit. Archäologie der literarischen Kommunikation II, München, Wilheim Fink, 1991.

${ }^{15}$ Sobre tot aixd, vegeu l'interessant estudi de M. Riesebrodt, Funda-mentalismus als patriarchalische Protestbewegung. Amerikanische Protestanten (1910-28) und iranische Schiiten (1961-79) im Vergleich, Tübingen, J.C.B. Mohr, 1990, esp. 21-24, 215-224. 
màgiques de les capes més pobres i socialment periferiques de les ciutats modernes ${ }^{16}$. En ell, freqüentment, $s$ 'hi barregen idees i pràctiques populars i heterodoxes amb representacions d'origen (ni que sigui molt remot) camperol $^{17}$.

En aquest article ens limitarem a considerar el primer tipus de fonamentalisme (el "racional"), que és, en definitiva, el que mostra unes afinitats més rellevants amb una concepció i organització monoteistes de la vida de l'individu i de les relacions socials que regulen la convivència quotidiana dels grups humans.

\subsection{L'abast del monoteisme}

Per regla general, hom acostuma a relacionar el monoteisme amb la religí i, d'una manera encara molt més concreta, amb la representació de la divinitat de les religions del tronc abrahàmic (judaisme, cristianisme, islam). En aquest sentit escriu Theodore M. Ludwig, "the term monotheism has generally been used theologically rather than for philosophical or cross-cultural descriptions of religion"18. El theos del monoteisme (sobretot, del monoteisme jueu) és un tsser diví que posseeix una supremacia i un poder absoluts, i governa l'univers seguint els impulsos de la seva voluntat omnipotent. Dient-ho altrament: d'acord amb una visió genuinament monoteista, Déu transcendeix, alhora, el món de les estructures recurrents (la natura) i la societat humana (la cultura). Déu, amb tot, no és el locus del poder diví, perquè Ell és justament el creador universal a partir del no-res (creatio ex nihilo). L'ésser humà, per la seva banda, troba seu el valor i la seva integració en la mesura en què colloca la seva creaturitat al servei (inicialment, litúrgic) de l'únic Déu's?.

La pregunta que cal plantejar-se tot seguit és la segũent: les idees $\mathrm{i}$ les representacions inicialment religioses són rellevants $i$ operatives exclusivament en l'àmbit (convencionalment) religiós o bé, per contra, mostren llur eficacia (positiva i/o negativa) en d'altres àmbits del pensament $\mathrm{i}$ de l'activitat dels humans? ${ }^{20} \mathrm{Si}$ hom prefereix eludir la "qũestió religiosa", hom podria preguntar-se: les idees $\mathrm{i}$ les representacions polítiques són rellevants $\mathrm{i}$ operatives exclusivament en l'àmbit (convencionalment) polític o bé, per contra, mostren llur eficàcia (positiva i/o negativa) en d'altres àmbits del pensament i de l'activitat dels humans? En el fons, els dos interrogants posseeixen nombrosos punts de confluència, perquè, a l'Occident, tostemps, una de les qüestions fonamentals (i mai no suficientment resolta) ha estat la relació de la religió amb la política. Aixd ens porta a formular la segũent afirmació, que no podrem justificar com fóra convenient: a l'Occident, la religio (el cristianisme) sempre ha posseît una exigència política, i la

${ }^{16}$ D'una manera gairebé exclusiva Riesebrodt, Op. cit., 36-39, 103-104, 108-111, 199-200, 224-228, considera que la fonamentalització actual és un producte de la mobilitat social que, en els temps moderns, es manifesta quasi exclusivament en els medis urbans.

${ }^{17}$ Cfr. Riesebrodt, Op. cit., 22.

${ }^{18}$ Th.M. Ludwig, "Monotheism": M. Eliade (ed.), The Encyclopedia of Religion X, New York-London, Macmillan, 1987, 69. Mai no s'insistira prou en el fet que, en les diverses arees politico-culturals, es donen uns tipus de "monoteisme pràctic" que $\omega_{n}$ irreconciliables entre si. Vegeu, per exemple, P. Ciholas, "Monothéisme et violence": Recherches de Science Religieuse 69(1981), 329-333, que ofereix els trets distintius del monoteisme jueu (profetic) i del monoteisme grec.

19 Cfr. Ludwig, Op. cit., 71-72.

${ }^{20}$ Acf hi ha una qüestió prèvia i fonamental que no pot ser plantejada amb el detall que caldria. Em refereixo a la definició de religió. Sobre aquesta problemàtica em permeto de remetre a L. Duch, Temps de tardor. Entre modernitat i postmodernitat, Montserrat, Publicacions de I'Abadia de Montserrat, 1990, 174-221, amb referència a la bibliografia més important. 
política sempre ha manifestat una apetència religiosa ${ }^{21}$. Dient-ho d'una altra manera: històricament, tant la religió com la política han intentat, amb una gamma molt àmplia de mitjans, procedir a una incorporació del seu oposat, de tal manera que, finalment i d'acord amb la gran varietat de contingències històriques que s'han donat, la religió abastés el camp de la política i la política el de la religio $6^{2}$.

El monoteisme, segons que ens sembla, ha estat -i, encara, és- el fonament "arqueològicament" més profund i consistent, que ha fet possible aquesta situació de mútua referència o, potser fóra millor de dir, d'incessant competició i exclusió entre religió i política: referència, relació $\mathrm{i}$ exclusió en la forma de "germans enemics". Però qui diu "religió i política" ve a dir la totalitat del camp del pensament, de l'acció i, sovint també, de la sentimentalitat dels humans. La IHlustració va adquirir el convenciment que el tradicional contenciós entre la religió i la política havia estat, finalment, solucionat. Per als uns, la paulatina autodissolució de la religió, atès el caràcter exclusivament històric que atorgaven a aquesta, i, per als altres, la seva obligada privatització, ja que la religió no tenia res a veure amb l'esfera pública, eren els senyals inequívocs de la reducció de l'antic conflicte entre religió i política; reducció que els iHustrats, naturalment, consideraven des d'una perspectiva política o, potser millor, pedagògica. Si hom admetia la "dissolució" del religiós, aleshores era possible afirmar que la totalitat de l'existència humana es podia reduir al camp de la política (o al de l'economia), sense que fes acte de presència, com en el passat, la intromissió deshumanitzadora de la religió com a factor competidor de les estratègies polítiques ${ }^{23}$.

\subsection{Què és el monoteisme}

Es convenient que ni que sigui d'una manera molt esquemàtica explicitem què entenem per monoteisme $^{24}$. Potser ja ha quedat suficientment subratllat que els comportaments monoteistes no poden reduir-se a l'àmbit convencionalment religiós, sinó que hom pot detectar-los en totes les parcelles del pensament i de l'activitat de l'ésser humà. No hi ha dubte que, en la tradició occidental, el monoteisme s'ha configurat diversament en les diverses cultures particulars que es troben integrades en aquest gran oced ideologic que anomenem "Occident". El monoteisme jueu, el qual, d'altra banda, va conèixer configuracions molt diferents en la llarga història del

${ }^{21}$ Ciholas, Op. cit., 330, eseriu taxativament: "Dans le monotheisme nous nous trouvons au coeur même du problème de la violence". Ací fóra oportú de referir-se al pensament de R. Girard, La Violence et le sacré, Paris, Grasset, 1972; Id., Des Choses cachées depuis la fondation du monde, Paris, Grasset, 1978; Id., La rufa antigua de los hombres perversos, Barcelona, Anagrama, 1989.

22 Vegeu sobre aquesta qüestió l'interessant article de R. Uertz, "Fundamentalismus: Theologisierung der Politik oder Politisierung der Theologie?": Kochanek (ed.), Die verdrangte Freiheit, ja citat, 53-71.

${ }^{23}$ Vegeu, sobre aquesta qüestió, els exceHents estudis de F.X. Kaufmann, Kirche begreifen. Analysen und Thesen zur gesellschaftlichen Verfassung des Christentums, Freiburg-Basel-Wien, Herder, 1979; Id., Religion und Modemirat. Sozialwissenschaftliche Perspektiven, Tübingen, J.C.B. Mohr, 1989.

${ }^{24}$ L'exposició que portem a cap del monoteisme és unilateral. Expressament volem deixar clar que en tot momeat ens referim a les consequùècies d'una idea, al seu discurs katafatic i no pas a la seva intima textura apofatica. Aquell "discurs extern", històricament, ha donat lloc a les majors aberracions. Sobre un tractament més complexiu de la problemàtica, vegeu el suggerent estudi de St. Breton, Unicité et monotheisme, Paris, Cerf, 1981. També caldria tenir present la interessant aportació de G. Ruggieri, "Dieu et pouvoir. Fonctionnalité politique du monotheisme?": Concilivon 197(1985), 29-40. 
judaisme $e^{25}$, presenta notables diferències respecte al monoteisme cristià, el qual també ofereix manifestacions molt contrastades, i, encara, pot afegir-se que es diferencia fortament de l'estricte monoteisme islàmic, el qual tampoc, malgrat les aparences, no és una magnitud sense fissure ${ }^{26}$.

Allo que sembla de cabdal importància en qualsevol discussió teòrica sobre el monoteisme és, de primer, l'èmfasi posada sobre el monos i, en segon lloc, els termes sobre els quals s'aplica aquest monos. Aquests són, fonamentalment, tres: Déu (o l'Absolut, o l'Englobant), el logos i el príncep. Amb aquests tres termes hom estableix d'una determinada manera tot l'abast de la realitat ${ }^{2}$. Un sol principi, que sense confondre's amb els artefactes materials o espirituals d'aquest món, és la font d'on brolla tot el que existeix i ho manté en l'existència. Aquest principi és absolut perquè és un u sense dos, és a dir, resulta irreductible a qualsevol realitat existent o pensable que no sigui ell mateix. La dicció d'aquest principi fontal, inclassificable i supremament autosuficient consisteix en un logos normatiu, és a dir, estableix un únic $\mathrm{i}$ exclusiu àmbit transitable (l'ortoddxia), al defora del qual les possibles altres diccions sobre el principi absolut són heterodoxes ${ }^{28}$. El principi absolut i transcendent adopta, doncs, una certa immanentització mitjançant el logos que analogicament l'expressa (i, alhora, no l'expressa). Hi ha, pero, una manifestació terrenal que s'interpreta com l'expressió més adequada, aquí baix a la terra, del principi únic, absolut i transcendent. Es tracta del príncep. Aquest és el lloctinent únic en l'ordre de la immanència del principi transcendent; adhuc hom li atribueix, en termes terrenals, les propietats que hom predica del principi absolut. Quan els processos de secularització que han tingut lloc a Europa desplegaran totes llurs virtualitats i l'estat, amb més o menys èxit, intentarà d'apoderar-se del "discurs teologic", abans detingut per l'església, aleshores el príncep i el seu discurs normatiu esdevindran els punts de referència absoluts de l'existència dels mortals ${ }^{x}$. En efecte, l'estat modern pretendrà una "immanentitzacio" total de l'existència, que mantingui, però, els antics atributs que antany, amb exclusivitat, s'aplicaven al Déu transcendent. En aquest sentit, per exemple, el "príncep" Stalin i el seu discurs infallible han estat unes aplicacions tragicament tangibles d'allo que pot significar el monoteisme després de la "mort del Déu celestial" i de la installació d'un deus mortalis ${ }^{30}$.

Per acabar de perfilar aquesta temàtica, ens cal referir-nos, ni que sigui breument, a la quiestió de la sobirania.

25 Vegeu H.G. Kippenberg, Die vorderasiatischen Erlösungsreligionen in ihrem Zusammenhang mit der antiken Stadtherrschaft, Frankfurt a.M., Suhrkamp, 1991, 133-138. "L'erreur de la conception monotheiste hẹbräque était de tout vouloir réduire à un principe religieux simple*(Ciholas, Op. cit., 353).

${ }^{26}$ Acf no podem entrar en la interessant quiestio a l'entorn del monteisme islàmic, el qual en alguns corrents xiltes rep unes formulacions extraordinàriament agosarades $\mathrm{i}$ aparentment no-monoteistes. Ha estat Henry Corbin el qui ha escudiat d'una manera molt aprofundida aquesta temàtica. Vegeu, per exemple, H. Corbin, Le paradoxe du monotheisme, Paris, L'Herne, 1981; Id., La imaginación creadora en el sufismo de Ibn 'Arabi, Barcelona, Destino, 1993, 108-124.

${ }^{n}$ En un breu article no és pas possible d'entrar en la complexa problemàtica a l'entorn dels diversos elements que participen en la constitució d'aquests tres grans principis.

28 Acf, com és obvi, caldria referir-se a la quêtestió de les Escriptures Sagrades en règim monoteista. Sobre aquesta quilestio, vegeu L. Duch, El libro en las religiones, Madrid, Fundación Santa Maria, 1989, passim.

29 Sobre l'abast que donen al "discurs teologic* i a la secularització com a canvi de propietari d'aquest discurn, que passa de les mans de l'església a les del príncep, vegeu Duch, Temps de tardor, ja citat, 44-47, 140-143, i un treball que estem preparant sobre la secularització $\mathrm{i}$ l'estat modern.

${ }^{30}$ Sobre la figura deus mortalis, vegeu més endavant. 


\subsection{La problemàtica a l'entorn de la sobirania}

Hom ha subratllat el fet que uri dels debats més intensos $\mathrm{i}$ apassionats que s'esdevingueren en la IHlustració se centrà a l'entorn de la sobirania. El progressiu augment de pes específic de l'estat posava en qüestió la constitució de la societat tradicional, que tenia en l'església com a lloctinent de Déu en aquest món el monopoli de la interpretació de les Escriptures Sagrades, les quals eren la pedra angular de la legitimació de la mateixa església i dels prínceps seculars. Aquest esmussament dels antics fonaments va obligar als ideòlegs dels segles XVII-XVIII (certament inquietats per la dolorosa presència de la "guerra civil") a replantejar sobre unes noves bases ideoldgiques les següents preguntes: Qui és sobirà? Quin és l'àmbit on el sobirà pot exercir la seva sobirania? Obviament, aquesta discussió va prendre unes dimensions molt diferenciades d'acord amb els convenciments més íntims dels interlocutors. Els qui van continuar mantenint l'existència d'un més-enllà, adoptaren unes posicions bastant diferents de les dels qui defensaven la negació de qualsevol mena de "supramón". En qualsevol cas, però, els esforços per legitimar la sobirania (i el sobirà) en la situació de modernitat que s'anava imposant foren extraordinàriament importants i decisius, i van permetre un nou plantejament del mapa polític, cultural i social del Vell Continent. Com a consequèencia d'aquest debat, hom va pretendre establir una nova relació entre religió i política; una nova relació que, per regla general, comportava l'anorreament progressiu o la privatització d'un dels termes del conflicte (la religio).

Un dels autors que més agudament va plantejar la problemàtica a l'entorn de la sobirania fou Thomas Hobbes, qualificat de "doctrinari de l'absolutisme reial" per Luigi Ciurra i d' "escriptor ombriu de la burgesia" per Jürgen Habermas". En el cap. XVIII ("Dels drets dels sobirans") del Leviatan, aquest pensador, per tal de superar els estralls del desordre (per exemple, en la forma de la guerra civil), afirma que cal que tots se sotmetin al poder absolut d'un de sol ${ }^{32}$. El concepte "poder" posseeix una funció decisiva en el pensament hobbesià. Cal no oblidar que l'atribut suprem de la divinitat, seguint la tradició teologica calvinista, és el poder (power). Hobbes, que es troba en el corrent d'aquesta tradició, és del parer que la divinitat és essencialment poder. Aleshores, la conclusió a què arriba el pensador anglès és molt senzilla: tot allò que és poderós, allà dalt al cel o ać baix a la terra, és diví. Per tant, segons l'opinió de Hobbes, Déu és sobirà "no com a Creador, sino com a Omnipotent". Hobbes, "literalment fascinat per la profunditat "vertiginosa" del poder", afirmarà que el sobirà ha de ser el veritable i indiscutible déu d'aquesta terra, perquè tant la divinitat, "allà dalt" al cel, com el sobirà, "aquí baix" a la terra, participen de la mateixa substancia: el poder configurat en forma de sobirania il-limitada Fent un pas endavant, Hobbes arribarà a afirmar: el príncep d'aquest món ho és perquè, amb el seu poder, és capaç de crear, a la terra, un món alternatiu al de Déu.

Les idees de Thomas Hobbes han tingut une enorme influència en la moderna configuració de l'estat; l'estat modern, 1 '"essència monoteista" del qual ha estat un dels factors que més poderosament han contribuit a la fonamentalització de les relacions humanes. En aquest sentit cal referir-se molt breument a Carl Schmitt, un dels ideòlegs més influents del nacionalsocialisme. En efecte, Schmitt fou un gran coneixedor i admirador dels teòrics de l'estat modern, especialment de

${ }^{31}$ J. Habermas, El discurso filosófico de la modernidad. Doce lecciones, Madrid, Taurus, 1989, 135. Vegeu Tobra cabdal en aquest sentit: Th. Hobbes, Leviatán. Edición preparada por C. Moya y A. Escohotado, Madrid, Editora Nacional, 1980. La introducció (p. 9-110) de Moya i Escohotado ofereix totes les dades desitjables per a situar i interpretar l'obra de Hobbes.

32 Massimo Cacciari denomina el Leviatan el "gran definidor", ja que disposa en exclusiva de la competència per establir l'abast tedric i pràctic dels mots i de les accions (ef. M. Cacciari, "Diritto e giustizia, saggio sulle dimezsioni teologica e mistica del moderno politico*: G. Penzo (ed.), Il potere. Saggi di filosofia sociale e politica, Roma, Citta Nuova, $1985,69-75)$. 
Jean Bodin i de Thomas Hobbes ${ }^{33}$. En relació amb aquest últim, Schmitt afirma que "la recerca de tota la meva vida gira, en particular, a l'entorn de l'obra de Hobbes"34.

Thomas Hobbes, d'acord amb la interpretació que en fa Schmitte, es troba a l'inici de la comprensió totalitzadora de la política que $s^{7}$ ha donat en la modernitat ${ }^{36}$. Malgrat les afirmacions en sentit contrari, Hobbes no "treballa" amb artefactes i expressions "mundans", condicionals, criticables i reformables, sinó que empra un "discurs teològic", incondicional i situat més enllà de qualsevol crítica, és a dir, "més enllà del bé i del mal". Una comprensió monoteista de la realitat com la que ofereixen Hobbes i Schmitt, ha de rebutjar la diferència com a quelcom atemptatori contra la seguretat i l'ordre, les quals són les virtuts supremes de la bona governació. Una governació, cal afegir, que és l'antídot més eficaç contra qualsevol situació de guerra civil ${ }^{37}$. Tant Hobbes en el segle XVIII com Schmitt entre el 1919 i el 1933 com les agrupacions actuals fonamentalistes (de caràcter convencionalment religiós o merament laiques), les quals experimenten amb més angoixa la creixent deslegitimació de moltes institucions (esglésies, estat, escola, familia), porten a cap una inequívoca afirmació monoteista, a fi d'evitar no ja un mer i teòric "politeisme dels valors" (Weber), sinó una situació que, d'acord amb llur opinió, representa el retorn al caos més indiferenciat, a l'anomia més vulnerable ${ }^{38}$.

Hi ha un aspecte del pensament de Carl Schmitt que voldríem destacar perquè, sens dubte, ajuda a comprendre millor l'abast i el sentit de l'actual fonamentalització en relació amb la qüestió de la sobirania. Amb anterioritat ja hem apuntat la importància del concepte "sobirania" per fer-se càrrec dels mecanismes constitutius de l'estat modern i del seu príncep. Schmitt es pregunta: en

${ }^{33}$ Hom no hauria d'oblidar, tanmateix, l'enorme influència que els pensadors reaccionaris del segle passat De Maistre, De Bonald i, sobretot, Juan Donoso Cortés, els quals es trobaven (o creien trobar-se) en una situació revolucionària com la de Hobbes al segle XVIII, van exercir sobre el pensament de Carl Schmitt. Vegeu C. Schmitt, Donoso Conies in gesamteuropäischer Interpretation. Vier Aufsătze, Köln, Greven, 1950, on exposa la seva recepció del pensador extremeny, el qual, curiosament, fou un dels pocs que foren traduitts a l'alemany durant la passada centúria. Més curiosament eocara, la recepcíó que l'Opus Dei ha fet del pensament de Donoso Cortés l'ha feta a través de l'obra de Carl Schmitt. Sobre aquest últim, vegeu L. Ciaurro, "Carl Schmitt: giurista della destra": I. Mancini (ed.), Hermeneutica. VI: La destra come categoria, Urbino, QuattroVenti, 1987, 193-223; M. Kaufmann, ¿Derecho sin reglas? Los principios filosóficos de la teoría del Estado y del Derecho de Carl Schmitt, Barcelona-Caracas, Alfa, 1989; N. Sombart, Die deutschen Männer und ihre Feinde. Carl Schmitt - ein deutsches Schicksal zwischen Männerbund und Matriarchatsmythos, München-Wien, Cart Hanser, 1991.

${ }^{34}$ C. Schmitt (1963), cit. Ciaurro, Op. cit., 195, nota 10.

35 Vegeu C. Schmitt, Der Leviathan in der Staatslehre des Thomas Hobbes. Sinn und Fehlschlag eines politischen Symbols, Köln, Hohenheim, 1982. La primera edició d’aquesta obra, que molts han considerat com el centre cabdal del pensament de Carl Schmitt, és del 1938.

${ }^{36}$ Sobre la concepcío de la politica com "das Totale", cfr. C. Schmitt, El concepto de lo polfíco. Texto de 1932 con un prólogo y tres corolarios, Madrid, Alianza, 1991. L'apologia de l'Església catòlica, eserita per C. Schmitt, Römischer Katholizismus und politische Form, Stuttgart, Klett-Cotta, 1984, en la seva etapa catòlica (1* ed. 1923, $2^{2}$ ed. 1925), es basa justament en la idea de totalitat: l'Església catòlica, amb els seus trets aristocratitzants, és l'únic baluard que, globalment, pot fer front a la desestructuració galopant de les relacions humanes, que porta a cap el món modern. Ha estat remarcat que el catolicisme reaccionari de Schmitt ofereix els trets d'una fortíssima nostàlgia teologico-simbòlica (M. Cacciari).

${ }^{37}$ Schmitt, Der Leviathan in der Staatslehre des Thomas Hobbes, ja citat, 34, arriba a afirmar: "L'estat, contínuament, representa l'evitació de la guerra civil".

38 Vegeu L. Duch, "Restauracionismo católico alemán de entreguerras (1918-1939)": Cristianesimo nella storia 12(1991), 639-682, on tracem alguns parahelismes entre la situació d'entreguerres (1918-1939) i el moment present. Tant aleshores com ara mateix, per part dels diversos fonamentalismes que funcionen en la nostra societat, hom intenta aplicar algunes "solucions monoteistes", fonamentades en el principi del líder, a una situació que hom interpreta com a politeista, pagana, dèbil, ete. 
definitiva, qui és sobirà? La resposta taxativa que aporta és: "és sobirà qui disposa de l'estat d'excepció"(Ausnahmezustand) ${ }^{39}$. El qui posseeix en propietat la capacitat de legislar (o d'abolir la legislacio fins aleshores vigent) d'acord amb els seus interessos, sense que li calgui fonamentar les seves decisions, aquest deté la sobirania en un sentit schmittià. La possessió del dret de declarar l'estat d'excepció per part del sobirà no es deixa fonamentar logicament: pertany de ple al camp de la voluntat $o$, potser més d'acord amb el pensament de Schmitt, al de la decisí. En aquest sentit afirma que "l'estat d'excepció té per a la jurisprudència una significació anàloga a la que tenien els miracles per a la teologia ${ }^{\mathbf{4 0}}$.

La infonamentació de l'aplicació de l'estat d'excepció, és a dir, de l'exercici de la sobirania del sobirà o, allò que ve a ser el mateix, de l'aplicació del principi monoteista a tots els àmbits de l'existència humana, es deu al fet que "tots els conceptes significatius de la moderna teoria de l'estat són conceptes teologics secularitzats"4!. Es tracta, en definitiva, d'unes transposicions "legals", però no "lògiques", de l'"àmbit celestial" a l'"àmbit mundà": hom continuarà afirmant o, per contra, negant l'existència d'un més enllà; allo, però, que importa, d'acord amb aquesta mena de pensament, és el manteniment de l'antiga exigència d'absolutesa que, antany, hom ubicava en el "cel", sota el comandament de Déu, representat en aquest món per l'església, i que ara, en la modernitat, se situa en "aquest món" esdevingut autònom. La titularitat o l'administració del "discurs teologic" ha canviat de propietari i d'ubicació geogràfica; l'exigència, però, continua mantenint-se dempeus. Un monoteisme sense déu o, per parlar com Hobbes, un monoteisme, una sobirania absoluta, sota el guiatge d'un deus mortalis, constitueixen, molt sovint, malgrat les aparences democràtiques, la base sobre la qual s'ha edificat la societat moderna i les seves fonamentalitzacions.

\section{Monoteisme i fonamentalisme}

"To look at fundamentalism without understanding monotheism is like taking a picture of waves and imagining that you have captured the turbulence of the ocean ${ }^{42}$. L'exposicio que hem portat a cap, que hauria d'haver estat molt més àmplia, a fi de copsar les nombroses i, sovint, molt subtils facetes de la problemàtica a l'entorn del monoteisme, tenia la intencionalitat de posar de manifest la relació directa que hi ha entre el principi monoteista i la fonamentalitzacio. "The foundational idea for fundamentalists is monotheism, and monotheis requires attachment to the ultimate paradoxe, a divine being at once transcendent and unknowable yet omnipresent and all-

39 Cfr. C. Schmitt, Politische Theologie. Vier Kapitel zur Lehre von der Souverănitat, München-Leipzig, Duncker \& Humblot, ${ }^{2} 1934,11,14$. "La decisió sobre l'excepció és, en el sentit més eminent, decisi6. Perquè una norma general, tal com habitualment la presenta la legislací6, mai no pot incloure una excepcí́ absoluta $i$, per això mateix, mai tampoc no pot fonamentar la decisió quan es dóna un autèntic cas d'excepci6"(id., 11). En un altre indret afirma que "la facultat đ'abolir la llei en vigor és l'autèntic senyal distintiu de la sobirania"(id., 15). El títol d'aquest llibre ("teologia política") ja indica prou elarament I'atmosfera general que "respira" Carl Schmitt; el seu subtitol ("quatre capitols de la doctrina de la sobirania") expressa nitidament el "lloc concret" on es fan els exercicis respiratoris.

${ }^{40}$ Schmitt, Politische Theologie, ja citat, 49; vegeu id., 50-66. Sobre la "teologia politica" de Schmitt, efr. Sombart, Op. cit., 58-81.

41 Schmitt, Politische Theologie, ja citat, 49.

42 B.B. Lawrence, Defenders of God. The Fundamentalist Revolt Against the Modern Age, London-New York, I.B. Tauris, 1990, 107. 
knowing"43. Aquesta afirmació de Bruce B. Lawrence és completament correcta si hom limita l'abast de la fonamentalització al camp convencionalment religiós, però resulta insuficient si hom és del parer que tots els àmbits i totes les activitats de l'existència humana són susceptibles de fonamentalitzar-se i, doncs, de configurar ideologies o personatges, dii mortales, que, encara que no mantinguin cap referència explícita a una transcendència supramundana, afirmin, amb tot, que detenen, en l'àmbit d'aquest món, una exigència d'absolutesa incondicional qualsevol. Dient-ho altrament: el fonamentalisme, perquè sempre posseeix una base monoteista (supramundana o intramundana, segons els casos), és, sempre $i$ arreu, un problema polític ${ }^{4}$.

La gamma de les fonamentalitzacions és molt àmplia per la senzilla raó que les possibilitats de "monoteïtzació" de l'existència humana $i$ de les seves relacions són també d'una enorme amplitud. En principi, gosariem afirmar que la totalitat dels sistemes socials, siguin de natura religiosa, econòmica, cultural, social o política, tendeix vers la fonamentalització perquè la recerca de principis incontestables assetja d'una manera inevitable el conjunt de les realitzacions humanes. I qui parla de principis incontestables, s'està referint, de fet, a la recerca d'un únic centre del sistema de referència, que imposa (o, almenys, ho pretén) una ortodòxia enfront de totes les altres opinions, praxis i actituds alternatives. Es tracta, en el fons, d'una aplicació conseqüent de l'esquema "amic-enemic" posat en circulació per Carl Schmitt els anys vint ${ }^{\text {tS }}$.

Si hom, per exemple, seguint Niklas Luhmann ${ }^{46}$, manté l'opinió que el món modern es caracteritza d'una manera notable per un incessant $\mathrm{i}$ imparable procés de complexificació dels sistemes i dels subsistemes socials, aleshores resulta explicable el procés de fonamentalització que, parallelament, apareix amb insistència en les societats modernes. Hom intenta, seguint l'argumentació de Luhmann, la "reducció de la complexitat", per tal de cercar i de trobar, ni que sigui provisionalment, el sentit, tot evitant l'embat de la perplexitat i de l'angoixa. Es un fet a bastament reconegut que l'home actual, en general, ha de fer front a la perplexitat (i, sovint, fins i tot a l'angoixa) d'haver d'elegir. Cal que esdevingui un heretge, per emprar una formulació de Peter L. Berger ${ }^{77}$. Els fonamentalismes proposen una teràpia per "reduir la complexitat" i per "guarir l'angoixa" que té com a base l'aplicació sense fissures d'un únic principi incontrovertible, infallible, monotérsticament configurat a tot el pensament i a totes les actuacions de l'ésser humà. Aquest, com a conseqūència d'aquesta cura, ja no es trobarà sotmès a les inestabilitats i el caprici de cap mena de "politeisme dels valors, de la moda i de les actituds".

Una conseqüència pràctica, que hom pot detectar en totes les menes de fonamentalització, és l'aparent senzillesa i la també aparent lògica esclatant de les doctrines proposades. Enfront de les "doctrines" de caràcter més o menys politeista, les quals, d'acord amb el judici de Françoise

${ }^{43}$ Lawrence, Defenders of God, ja citat, 106. Sobre el monoteisme interpretat fonamentalisticament per les "religions del llibre", vegeu l'exceHent exposició de Lawrence, Op. cit., 107-119.

44 Aef caldria referir-se a l'assaig d'E. Peterson, "El monoteísmo como problema político": Tratados teológicos, Madrid, Cristiandad, 1966, 27-62, 259-282, que fou publicat el 1935, contra la pretensio de Carl Schmitt de fonamentar una teologia politica. Sobre el sentit i l'abast d'aquesta controvèrsia, vegeu B. Nichtweiss, Erik Peterson. Neue Sidt auf Leben und Werk, Freiburg-Basel-Wien, Herder, 1992, 727-830. Barbara Nichtweiss aporta totes les dades necessaries per fer-se càrrec del complicat rerafons de la polèmica entre Peterson i Schmitt.

45 Vegeu C. Schmitt, El concepto de lo politico, ja citat.

${ }^{46}$ Cfr. N. Luhmann, Funktion der Religion, Frankfurt a.M., Suhrkamp, 1977, esp. 189-224; Id., Soziale Syzeme. Grundriss einer allgemeinen Theorie, Frankfurt a.M., Suhrkamp, 1984, passim.

47 Vegeu P.L. Berger, Der Zwang zur Haresie. Religion in der pluralistischen Gesellschaft, Frankfurt a.M., S. Fixcher, 1980. 
Champion, constitueixen una "nebulosa místico-esotèrica"48, els enunciats teòrics, les actituds concretes i les decisions político-religioses de caire fonamentalista es distingeixen per una enorme linealitat que, molt sovint, ve a ser una mena d'Illustració a l'inversa. Enfront de l' "atomització de l'univers de les representacions de les societats modernes" (D. Hervieu-Léger) i de l' "opacitat del món"(H. Arendt), que dificulten enormement la vertebració de l'individu i de la collectivitat, els corrents fonamentalistes ofereixen un tot coherent, monotésticament estipulat, amb una distinció clara i tallant de les pautes de conducta, amb els consegūents premis i càstigs que l'acompanya. No costa pas massa de comprovar que la "modernitat viscuda es presenta (...) com l'experiència d'un món canviant, en moviment, diferenciat, com l'experiència d'un món "a fer" "49. L'acusació d'anomia, d'esmicolament de la societat, és una constant en les denúncies que fan els líders fonamentalistes ${ }^{50}$. Segons Martin Riesebrodt, la transformació del tradicionalisme en fonamentalisme s'esdevé com a conseqũència de l'anomia imperant en moltes societats de l'Est i de l'Oest; anomia que s'expressa principalment a través de quatre factors: 1) esfondrament de l'ordre social (moral) vallid fins aleshores; 2 ) injustícia social, experimentada per les capes més pobres de la societat; 3 ) procés de deslegitimació de l'estat com a consequència de la seva incapacitat per assegurar l'ordre i la justícia; 4) invasió en l'àmbit de l'estat i de la societat de corrents de pensament i d'actuació d'origen estranger ${ }^{51}$. Gilles Kepel, per la seva banda, afirma que els moviments fonamentalistes "sont porteurs d'un sens; ils ne sont pas le produit d'un dérèglement de la raison ou d'une manipulation par des forces obscures, mais le témoignage ireemplaçable d'un malaise social profond que nos catégories de pensée traditionnelles ne permettent plus de décrypter" 52 . En un mot: en tota tendència fonamentalista hi ha, en graus $i$ amb intensitats molt diversos, una "disqualification d'une laïcité qu'ils (els fonamentalistes) font remonter à la philosophie des Lumières 53 .

La contrapartida que els fonamentalismes (sobretot els de caràcter religiós i polític) fan a la modernitat consisteix primordialment en la reconstrucció d'un nou cosmos sagrat, piramidalment estructurat, perquè tot fonamentalisme ( $i$, en el fons, qualsevol "sistema" en tant que, inevitablement, es troba sotmès a un procés de fonamentalització) és una teodicea (en el sentit de Max Weber) o, potser encara millor, una "monodicea", una superació del "mal", és a dir, de la

48 Vegeu F. Champion, "La nébuleuse mystique-ésotérique. Orientations psychreligieuses des courants mystiques et ésotériques contemporains": F. Champion - D. Hervieu-Léger, De l'émotion en religion. Renouveaux et traditions, Paris, Centurion, 1990, 17-69. Per comprendre la "Iogica" de l'esoterisme contemporani, of. J.-L. Schlegel, "Néo-ésotérisme et modernité": R. Ducret - D. Hervieu-Léger - P. Ladrière, Christianiome et modernité, Paris, Cerf, 1990, $273-293$.

49 D. Hervieu-Léger, "Les manifestations contemporaines du christianisme et la modernite": Ducret - Hervieu-LEger, Ladrière (ed.), Christianisme et modernite, ja citat, 296-297.

50 Vegeu, per exemple, G. Kepel, La Revanche de Dieu. Chrétiens, juifs et musulmans à la reconquête du monde, Paris, Seuil, 1991, 17.

51 Vegeu Riesebrodt, Op. cit., 239-241.

52 Kepel, Op. cit., 26. Sobre el fonamentalisme com a negació de la modernitat, vegeu S. Abbruzzese, Comunione e liberazione. Identité catholique et disqualification du monde. Préface de Jean Séguy, Paris, Cerf, 1989; Pace, Il regime della veritd, ja citat; Th. Meyer, Fundamentalismus. Aufstand gegen die Moderne, Reinbek b. Hamburg, Rowohlt, 1989.

${ }^{53}$ Kepel, Op. cit., 260. Abbruzzese, Op. cit., passim, resumeix els diversos aspectes de la ideologia de "Comunione e liberazione" amb l'expressió "disqualification du monde". Cal entendre: del món modern assentat sobre la democracia, la igualtat d'oportunitats i la igualtat de tothom davant la llei. 


\section{Fonamentalització $\mathbf{i}$ idea d'elecció}

En tot procés de fonamentalització com aplicació concreta de la ideologia monoteista, hom pot detectar-hi una vella idea teològica secularitzada ${ }^{55}$. Ens referim a la idea d'elecci $6^{56}$. A l'Occident, aquesta situació s'origina en el transcurs de la història del poble d'Israel, i es concreta en estret parallelisme amb l'afirmació monoteista d'aquell poble, el qual "passa" d'una concepció politeista a una altra d'henoteista fins a arribar, finalment, a l'afirmació deuteronòmica de caràcter francament monoteista. No hi ha dubte, doncs, que l'elecció constitueix l'aspecte central de l'autocomprensió del poble jueu. La idea d'elecció, però, de la mateixa manera que les afirmacions monoteistes, comporta una actitud exclusivista: elegits i no-elegits no poden collocar-se en el mateix sac; més encara: els elegits són plenament conscients de llur dignitat incomparable, la qual es pot traduir en comportaments racials, religiosos, sexuals, culturals i historrics; aquesta suposada dignitat els pot exigir des de la supeditació sense miraments dels "altres" fins a llur total anorreament ${ }^{5}$. Hom podria concretar tot el que hem exposat dient que s'esdevé el pas des d'una teologia de l'elecció a una ideologia de l'elecció, perquè, com apuntàvem en començar aquest article, les idees religioses sempre són políticament actives, i les idees polítiques mai no deixen de tenir una exigència religiosa.

Molt breument voldríem exposar alguns exemples concrets, on és possible de detectar in actu exercito la coimplicació fonamentalització-monoteisme (elecció), tot tenint en compte el que hem exposat anteriorment.

\subsection{Fonamentalització i minoria}

En la historia dels pobles i de les cultures marcats, ni que sigui d'una forma merament cultural, per les religions del llibre, el concepte de minoria ha posseit una enorme importàncias". Quan es dóna un procés de fonamentalització, hom subratlla amb intensitat, al mateix temps, la consciència de minoria elegida (de "fills de la llum en combat contra els fills de les tenebres") per

54 Sobre la teodicea weberiana, efr. Schluchter, Religion und Lebensfilhrung I, ja citat, 351-357.

55 Volem cridar l'atenció sobre la idea, ja exposada per Carl Schmitt, que tots els conceptes de l'actual teoria de l'estat són conceptes teologics secularitzats. Potser caldria donar un pas endavant $i$ afirmar que tots els conceptes $i$ totes les representacions que tenen alguna cosa que veure amb la conquesta o l'exercici del poder són conceptes teològics secularitzats; i, molt més concret encara: són representacions o conceptes derivats molt directament de la ideologia monoteista.

${ }^{56}$ R. Panikkar, "Chosenness and Universality: Can Christians Claim Both?": Cross Currents 38(1988), 309-324, 339, ofereix les bases per a una interpretació diferent de la idea d'elecció. La quêestió que roman dempeus és si la seva comprensí́ de l'elecció pot encabir-se encara dins la figura tradicional de l'elecció, o bé si Panikkar ja està referint-se a quelcom de completament diferent. Una discussió detallada de la idea d'elecció en I'Antic Testament ofereixen W.A. Irvin, El pensamiento prefilosófico. II: Los hebreos, México, Fondo de Cultura Económica, '1968, esp. cap. IV (142-187); H. Seebass, "Erwählung I (Altes Testament)": Theologische Realenzyklopadie X, Berlin-New York, W. de Gruyter, 1982, 189. 189.

57 Irwin, Op. cit., 148, 149, escriu: "L'arrel vital i la mateixa essència del sentiment hebreu de diferenciació radiquen en la singularitat del Déu d'Israel (...) Aquesta doctrina de l'elecció ha estat una font de supèrbia nacional".

${ }^{58}$ Acf, obviament, no tenim en compte de forma primària la funció de les "minories dominants" enfront de la "massa" tal com l'exposa M. Weber, Economía y sociedad. Esbozo de sociología comprensiva II, México-Buenos Aires, Fondo de Cultura Económica, ${ }^{2} 1964,704-706$. 
part dels qui se senten "tocats" per un missatge radical i la peremptoria necessitat d'eliminar físicament els adversaris. Parallelament s'imposa el retorn al "ghetto", és a dir, al lloc on serà possible una existència completament pura i incontaminada ${ }^{59}$. Perquè cal no oblidar que, al bell mig de la diàspora, sols es pot sobreviure mitjançant una fortíssima "ghettificació" de les representacions $\mathrm{i}$ de les relacions socials.

La idea de minoria sembla comportar l'existència d'un petit grup, detenidor de la veritat absoluta, que ha de fer front als "fills de les tenebres", la qual cosa implica un encastellament sense concessions sobre si mateix: en ell, l'esquema "amic-enemic" s'aplica amb la màxima intensitat i extensio. De tota manera cal advertir que, històricament, hi ha hagut grups majoritaris en llur àmbit geopolític que han mantingut els comportaments típics de les minories autèntiques ${ }^{60}$. L'Iran de Khomeini n'és un bon exemple. En aquest cas concret, però, hom no hauria d'oblidar que foren els mateixos occidentals els qui contribuiren decisivament que el règim iranià fos considerat com una "minoria diabolica". "Since Imam Khomeini's ascent to power in Iran in early 1979, Islamic fundamentalism has been targeted by the American news media as the bête noire of American interests in the Middle East" ${ }^{\prime 1}$.

D'una manera constitutiva pertany a les ideologies fonamentalistes el nativisme. Tota crisi no és autòctona, sinó importada de l'exterior. Aixo significa, d'una banda, que cal desterrar o eliminar l'estrany, perquè posa en qũestió la pròpia identitat. I, de l'altra, s'imposa el retorn als origens, a les arrels polítiques, culturals i religioses que donaren origen al grup ${ }^{62}$. El grup dels elegits, però, no és sinó una petita minoria (o una majoria amb comportaments de minoria). Això no el priva de posseir la "consciència de David" contra el "Goliat" de torn. Acf caldria insistir en un aspecte molt típic dels grups fonamentalistes, sobretot quan prenen consciència de llur situació de minoria. Ens referim a la lluita sense treva que han de menar contra el mal. Un mal que es manifesta en forma de conspiració de la "bèstia diabolica" contra els purs, contra la petita resta. Recordem, per exemple, la "conjura marxista-judeo-masónica", la qual era presentada per la dictadura franquista com la concreció del "mal radical" que, finalment, seria vençut i bandejat pel "centinela de Occidente". En la ideologia khomeiniana, els occidentals (nord-americans, britànics, russos) són presentats com els conjurats que actuen sota les ordres directes de Satanàs, el braç armat dels quals és, en general, el sionisme internacional i, d'una manera molt més concreta, l'estat d'Israel.

La consciència de minoria porta aparellada una vigència sense límits de 1' "estat d'excepció", en la forma que l'interpreta Carl Schmitt, com a forma normal de convivència política, religiosa i social. Si hom esta convençut de trobar-se en el final dels temps, en l'hora decisiva de la batalla entre els fills de la llum i els fills de les tenebres, aleshores no hi ha legalitat que valgui: tot és excepcional, perquè la urgència de l'últim moment és, d'alguna manera, "extratemporal" i "extraterritorial". La consciència de minoria, a més, redueix l'abast de l'exercici de l'ofici d'home a la voluntat. Com el Déu exclusivament monoteista, que és qualifica per ser únic, acte pur,

59 Cfr. Kepel, Op. cit., 269-271.

${ }^{60}$ Un aspecte del funcionament de la minoria elegida que hom no pot descurar és el de la "minoria dins la minoria". En el cas de l'Iran khomeinià, la minoria de la minoria està formada pels mujtahids, que sovint provenen de les families dels grans comerciants i dels latifundistes, els quais han rebut la missió divina de conduir vers la plena realització la "minoria popular" (cfr. Riesebrodt, Op. cit., 181-186).

${ }^{61}$ Lawrence, Defenders of God, ja citat, 190. Una de les millors anallisis del fonamentalisme xiita, sobretot de la personalitat de Khomeini, és la de Riesebrodt, Fundamentalismus als patriarchalische Bewegung, ja citat, 123-213, esp. 152180.

${ }^{62}$ Vegeu Riesebrodt, Op. cit., 170-171. 
decisió que no pot encabir-se en les lógiques humanes, la minoria que regeix els grups fonamentalistes (amb una clara consciència de minoria) també participa, ací a la terra, de la disposició original de Déu formulada exclusivament en termes de voluntat infonamentada i infonamentable.

En resum, doncs: la idea de minoria implica, en el temps de la gran tribulació i del descabdellament illimitat del mal, una aplicació molt activa $\mathrm{i}$, sovint, àdhuc belligerant, de la idea teològica i eminentment monoteista, d'elecció. Una elecció religiosa, que molt ràpidament esdevé una elecció política i cultural contra tots "els altres".

\subsection{Fonamentalització i la dona}

D'una manera molt genèrica, però no necessàriament incorrecta, hom pot afirmar que els corrents fonamentalistes posseeixen una indubtable faceta antifeminista $o$, si hom vol expressar-ho d'una altra manera, que el monocentrisme típic de qualsevol mena de fonamentalisme s'assenta de manera exclusiva en el "principi paternal" o, potser fóra més adequat de dir, en el mascle com a tipus insuperable de l'humà i del diví. Es possible de donar raó d'aquest fet a partir de consideracions molt diverses. En aquesta exposició, però, voldríem cenyir-nos a la consideració general que hi ha estat present constantment, és a dir, al monoteisme.

Un dels components operatius més antics de la comprensió monoteista és l'exclusió de la femeneitat del concepte de Déu ${ }^{63}$. Ací no ens és pas possible de seguir fil per randa aquest procés històric, el qual comporta, ací a la terra, l'organització patriarcal de la societat ${ }^{64}$. El concepte de Déu (o de la divinitat) que preval en una determinada societat no és alguna cosa indiferent respecte a la seva organització $i$ la jerarquització que imposa als seus membres ${ }^{65}$. En la seva inevitable tendència vers la fonamentalització, una societat monoteísticament organitzada tendirà a privilegiar, quasi d'una manera exclusiva, el paper de l'home, tot relegant el de la dona a un lloc molt secundari $i$, fins $i$ tot, comparable al dels esclaus, dels infants $i$ dels disminuīts mentals $s^{66}$. La directa correspondència entre 1 '"altre món" i "aquest món" s'expressa sobretot mitjançant la correspondència entre el déu del més enllà i el mascle que, en el més ençà, n'es el seu lloctinent. A l'Occident, quan comencin a intervenir els processos de secularització, continuarà mantenint-se la preeminència del deus mortalis intramundà, amb tots els atributs i prerrogatives que antany s'atribuien al deus immortalis.

En els nostres dies es dóna una fortíssima tensió entre corrents d'encuny politeista, que sovint prefereixen anomenar-se a si mateixos "pagans" 0 "neopagans" ${ }^{47}$, i uns moviments, sovint

${ }^{63}$ Vegeu G. Baudler, Gott und Frau. Die Geschichte von Gewalt, Sexualităt und Religion, München, Kōsel, 1991.

64 Vegeu, per exemple, Chr. Mulack, Die Weiblichkeit Gottes. Matriarchale Voraussetzungen des Gottesbildes, Stuttgart-Berlin, Kreuz, 1983; R.R. Ruether, Sexismus und die Rede von Gort. Schritte zu einer anderen Theologie, Gütersloh, Gerd Mohn, ${ }^{2} 1990$.

${ }^{65}$ Acf no cal entrar en la polèmica sobre l'autocomprensió de I'bome com a "imatge de Déu (o dels déus)". En tơ cas, I" antropologia" és primera respecte a la "teologia".

${ }^{\infty}$ Aquesta asseveració que, segons que pensem, és històricament correcta, caldria completar-la amb una altra, no meays evident. En les societats marcades per una "monoteitzacio" intensa de la convivència col-lectiva (Egipte, Israel, Grècia), acostumen a fer acte de presència tendències de tipus sapiencial, les quals vénen a ser "argumentacions contra el sistema", per emprar una expressió de Paul Feyerabend.

${ }^{67}$ Hem estudiat el "retorn dels déus" a Les dimensions religioses de la comunitat, Montserrat, Publicacions de I'Abadia de Montserrat, 1992, cap. V (111-129), on oferim la bibliografia més important sobre aquesta qũestió. En aquest context caldria tenir en compte l'anomenada "nova dreta". Vegeu-ne alguns textos significatius a A. de Benoist - G. Faye, Las ideas 
extraordinàriament militants, de tipus monoteista (fonamentalista). D'una banda, retornen els déus o, potser millor, l'antiga deessa de la terra bandejada pel triomf del patriarcalisme monoteista, i, de l'altra, s'imposen tendències sacro-polítiques, que pretenen la configuració d'una societat homogènia, articulada piramidalment mitjançant un adequat ús del "principi del lifder". En aquest darrer cas es tracta, de fet, d'una organització sòcio-cultural que exclou la diferència, la qual, en relació amb el tema específic que ens ocupa, pot resumir-se amb la sigla "dona".

Com a conclusió, podem dir que la idea d'elecció aplicada a la quiestió que ara ens ocupa es podria resumir d'aquesta manera: l'elecció d'un poble, que és la manera social com es manifesta, en l'espai $\mathrm{i}$ en el temps, la voluntat electiva de la divinitat, es concreta encara d'una manera més quotidiana en l'elecció d'un sexe, la qual cosa comporta l'exclusió $i$, fins i tot, la demonització de l'altre sexe. Hom intenta de donar consistència a l'exclusió de la dona, tot afirmant que la divinitat és de natura exclusivament masculina, perquè en la femeneitat es troba l'origen del mal, del pecat, de la pollució, de la mort i de la feblesa.

\subsection{Fonamentalisme i creació d'un enemic}

Sobre l'esquema "amic-enemic" ja n'hem dit alguna cosa arran de l'exposició del pensament de Carl Schmitt. La creació d'un enemic exterior és de cabdal importància per als grups amb tendències fonamentalitzadores. Cal afegir que la presència d'un enemic exterior es dedueix sense esforç de qualsevol mena d'actitud monoteista, ja que enfront de l'únic Absolut i del discurs que l'expressa no és permissible l'existència de cap competidor. Aleshores és possible de polaritzar el "no-jo" dels adeptes del grup a l'entorn d'unes figures i d'unes representacions que hom qualifica despectivament d'ídols o d'adoradors dels idols.

Carl Schmitt assenyalava que la "construcció" de l'enemic és un afer decisionista, és a dir, hom, conjunturalment, n'estableix la fesomia, li atribueix les (perverses) intencions que més convinguin i, si el curs dels esdeveniments ho aconsella, "aquell" enemic pot esdevenir un "amic de tota la vida"6s. En qualsevol cas, cal un artefacte extern a l'entorn del qual es construeixi la pròpia identitat interna. Més encara: un artefacte extern, un "enemic simbòlicament individualitzat" (com diu Enzo Pace en relació amb "Comunione e Liberazione") ${ }^{6}$, una negativitat de caràcter diabðlic i antidivi, que permeti una total "desqualificació teologica", és a dir, sense parliatius, de l'altre.

\section{Conclusi 6}

Politeisme i monoteisme han estat dues formes antagoniques que, a l'Occident, han intentat d'organitzar l'existència humana en totes les seves facetes i modalitats ${ }^{70}$. Ara mateix, la societat occidental es troba esquinçada per aquestes dues formes extremes d'interpretar la vida i donar-li consistència teòrico-pràctica. Els actuals moviments adscrits al new age, d'una banda, i les innmobrables tendències fonamentalitzadores que hom pot detectar en la nostra societat, de l'altra, constitueixen plasmacions molt concretes de politeisme i de monoteisme, d'afirmació de la diferència, que, curt i ras, pot arribar fins a la dissolució, i de monocentrisme militant, que,

de la "nueva derecha". Una respuesta al Colonialismo cultural, Barcelona, Nuevo Arte Thor, 1986.

${ }^{68}$ En el cas de l'Alemanya de temps de Schmitt, aquesta conversió es veí́ concretada en el pacte germano-soviètic.

69

Pace, $I l$ regime della verita, ja citat, 89-91, 101.

70 Vegeu el llibre de M. Augé, Genie du paganisme, Paris, Gallimard, 1982. 
senzillament, pot arribar fins a la total robotització del subjecte. Amb aquesta robotització del subjecte, els líders pretenen la creació, per emprar una expressió de Michel Foucault, del règim de la veritat absoluta.

En aquest article ens ha interessat molt en primer lloc la innegable relació entre monoteisme i fonamentalització. Cal afegir, però, que, almenys implícitament, hom ha de tenir en compte el seu pendant, perquè la demarcació de qualsevol camp intellectual sempre es porta a cap en relació amb una "exterioritat", la qual a contrario és imprescindible per perfilar-la i donar-li concreció.

El fonamentalisme com a expressió de la "monoteització" de l'existència humana és un fenomen modern, que intenta ser una resposta als desafiaments i, sobretot, a la desestructuració simbòlica que, tan agudament, experimenta l'home contemporani. Sovint, fins i tot, els corrents fonamentalitzadors s'especifiquen per un ús molt actualitzat de la tecnologia més moderna, de tal manera que Enzo Pace arriba a afirmar que els corrents fonamentalistes dels nostres dies, en llurs àmbits concrets d'influència, es mostren capaços "d'unir el màxim d'arcaisme amb el màxim de sapient manipulació de l'imaginari collectiu per mitjà del llenguatge dels mass media ${ }^{71}$. Per això pot asseverar-se que el fonamentalisme és una forma central de la modernitat, "una forma moderníssima, per mitjà de la qual s'expressa el conflicte entre la religió i la política" ${ }^{n}$.

El fonamentalisme com a "monoteisme polític" és l'intent, mai no separat de l'ús de l'"arma econòmica", per restablir unes estructures intełlectuals $i$ axiologiques basades en un sol Déu, un sol discurs i un sol príncep. Això en termes "religiosos" o "seculars".

${ }^{71}$ Pace, Il regime della veritd, ja citat, 9; cfr. id., 43. Kepel, La Revanche de Dieu, ja citat, 108 (amb referèocia a "Comunione e Liberazione"), 189 (amb referència al fonamentalisme americà), 191, afirma el mateix. 